\title{
Investigations on Timber
}

$\mathrm{U}$

NDER the auspices of the Department of Scientific and Industrial Research, the report of the Forest Products Research Board for the Year 1931 has been issued. It is combined with the report of the Director of Forest Products Research for the same year.

The investigations carried on during the year fall roughly into three groups: (1) the dry rot investigations being carried out in the new experimental building erected for the study of this subject, (2) investigations into the death-watch beetle and into the damage caused by the Lyctus powder-post beetles, and (3) investigation work on Empire timbers, more especially in the tropical hardwoods. Under (3), the report of the Research Board has some pertinent remarks on the subject of encouraging and organising the placing of Empire tropical timbers on the markets. Several of the points discussed have been already alluded to in NATURE $(129,696$, May 7, 1932).

The report describes improvements in the design of seasoning kilns, new apparatus for the determination of humidity in the kilns, and a method of employing the photoelectric cell in the study of wood structure by using it to measure the percentage of empty space in the interstices of a timber due to its cell structure. Apparatus is also described which determines the gloss of a machined surface by measuring the amount of light scattered or reflected from it. Another instrument measures the finish on a surface by recording the frictional resistance experienced by dragging a standard metal plate over the surface.

The report emphasises the importance of research on wood-working tools. "A new Empire timber is often condemned by the machinist as 'unworkable' simply because machines, developed to deal with timbers in common use, are not suited to the very different structure of the new timber. A modification of feed speed, cutting speed or cutting angle may be all that is necessary to make the most obdurate timber workable, but in order to foretell these modifications a knowledge of the way in which the eutting action of any tool, whether plane, saw or drill, should be related to the structure of the wood on which it is to work is essential."

During the year, 689 specimens of structural timber were tested, while 3,470 test pieces cut from a material free from knots, etc., were submitted to almost every conceivable mechanical test. Tests on physical properties, etc., numbered more than 9,500. A total of 4,800 specimens treated in various ways with eight wood preservatives, including low temperature tar and its distillates, have been exposed for test and are kept under constant observation.

\section{Antarctic Geology and Glaciation*}

$\mathrm{T}$ HE sub-antaretic islands south of the Indian Ocean-Prince Edward and Marion Islands, the Crozet Islands, St. Paul and Amsterdam Islands, the Kerguelen Archipelago, and Heard Island-are all of the character of oceanic islands. So also is Macquarie Island in the Australian sub-antarctic. They are the summits of vast igneous extrusions heaped upon the sea floor. Volcanic activity has ceased only in recent times. Hot springs are still met with at St. Paul and have been vaguely reported from Korguelen Island. All those islands in higher latitudes than $40^{\circ} \mathrm{S}$. show evidence of severe glaciation during geologically recent times. Glaciers are still a feature of Kerguelen Island, Heard Island, and the Crozets. As a consequence, morainic debris, fluvial sands, and peat beds occur irregularly distributed over their surface.

Magmas contributing to the formation of these islands are, in the main, very basic. Varieties of peridotite, basanite, and basalt have been extruded on a vast scale. Next in order of abundance but subordinate in quality is an interesting range of trachytes and phonolites. Coarse tuff beds on Macquarie Island, Heard Island, and Kerguelen contain fragments of a dense, recrystallised Globigerina ooze, indicating that the igneous outbursts have broken through pelagic sediments. The occurrence of unsaturated magmas amongst the volcanic effusions may be attributable to the assimilation of quantities of such calcareous oozes.

Acid lavas are scarce, the only notable record so

* Substance of a lecture entitled "Geology and Glaciation of some Islands of the Southern Ocean and the newly discovered Antarctic Mainland" delivered by Sir Douglas Mawson at the Geological Society of London on May 10. far being the appearance of rhyolite amongst the earlier eruptive debris of St. Paul Island.

Macquarie Island is unique amongst these localities in exhibiting some of its basic igneous rocks in an advanced state of serpentinisation. There, also, are found former submarine volcanic centres where tachylite now considerably palagonitised was extruded.

Kerguelen, which is much larger than any of the other islands under consideration, also reveals a more complicated geological structure. This appears in the deep fjords, where sections are exhibited cut down through several thousand feet of strata. In the south-western portion of the island, there are thus brought to light plutonic rocks such as mon. zonite, mica-diorite, and even syenitic types. Those have doubtless originated, as Lacroix has explained, by injection into the already solidified effusive lava system.

Chronological evidence is limited and is so far found only at Kerguelen. There, a land surface composed of igneous rocks, basalts, trachytes, and the like, appears to have been in existence in early Tertiary times. Upon this surface, fluviatile conglomerates were laid down on a grand scale. These incorporate in their upper limits irregular intercalations of lignite. The fossil vegetation recorded is dominated by an Araucarian flora very similar to that existing to-day in the considerably warmer climate of Norfolk Island. The age of this lignite is likely to be late Oligocene.

Thereafter follows a vast succession of basalt flows and ash beds, high up in which series has bcen located a band of coarse littoral sediment rich in fossil mollusca with a Pliocene facies. The mollusca, by their nature, indicate water warmer than prevails 